\title{
Izborno zakonodavstvo Bosne i Hercegovine - rodna analiza
}

\author{
Amila Ždralović \\ Docentica Pravnog fakulteta Univerziteta u Sarajevu \\ a.zdralovic@pfsa.unsa.ba
}

\begin{abstract}
Sažetak: U ovom radu ponudit će se rodna analiza potreba i mogućih pravaca reforme izbornog zakonodavstva Bosne i Hercegovine. Fokus rada će biti na tri centralna istraživačka pitanja. Prvo, analizirat će se u kojoj mjeri i na koji način konsocijacijski politički sistemi o(ne)mogućavaju predstavljanje žena u politici. Pri tome će se u obzir uzeti različite dimenzije predstavljanja (formalno, deskriptivno, sadržajno i simbolično predstavljanje). Drugo, analizirat će se da li je Izborni zakon Bosne i Hercegovine usklađen sa Zakonom o ravnopravnosti spolova Bosne i Hercegovine. I treće, ispitivat će se u kojem pravcu se trebaju i mogu odvijati reforme izbornog zakonodavstva $\mathrm{BiH}$. U tom kontekstu biće predstavljene i preporuke CEDAW komiteta i različite rodno odgovorne inicijative za reforme izbornog zakonodavstva koje dolaze kako od institucija nadležnih za rodnu ravnopravnost, tako i iz sfere civilnog društva.
\end{abstract}

Ključne riječi: politička participacija žena, ženske kvote/rodne kvote, afirmativne mjere, Izborni zakon $\mathrm{BiH}$

\section{Uvod}

Godine 2020. obilježava se 25 godina od usvajanja Pekinške deklaracije i Platforme za akciju i 20 godina od usvajanja Rezolucije 1325 Vijeća sigurnosti UN-a „Žene, mir i sigurnost”. Ciljevi ovih dokumenata usmjereni su velikim dijelom na stvaranje boljih uslova za političko predstavljanje žena. Preliminarno se može konstatovati da su uloženi napori koji su uslijedili uslovno i djelimično na globalnom nivou polučili uspjehe prije svega u sferi ravnopravnog učešća žena u političkom životu. Ipak, u obzir treba uzeti i različite vrste političkog predstavljanja i specifičnosti društveno-političkih konteksta. U ovom radu se otvara rasprava o specifičnostima bosanskohercegovačkog političkog sistema i preprekama adekvatnom predstavljanju žena u politici u svjetlu različitih dimenzija predstavljanja. Pri tome se kao poseban problem identificira nemogućnost supstancijalnog predstavljanja žena, a time i korištenja kreativnih potencijala u proizvodnje suštinskih društveno-političkih i ekonomskih promjena. Međutim, u skučenim postojećim okolnostima, 
pronalaze se mogućnosti korekcije uz koje bi se povećalo bar deskriptivno predstavljanje žena. U raspravi se polazi od dvije prethodne teze o deskriptivnom predstavljanju. Prva je uvjerenje da ono može dovesti do pozitivnih promjena u supstancijalnom predstavljanju. A druga je, kako ipak ne postoji garancija za suštinske promjene politika, da je ono samo po sebi nužno radi ravnopravne raspodjele moći između muškaraca i žena. U radu se pokazuje da deskriptivno političko predstavljanje žena zavisi od načina usklađivanja Izbornog zakona Bosne i Hercegovine sa Zakonom o ravnopravnosti spolova Bosne i Hercegovine. Potpora tvrdnje da su reforme izbornog zakonodavstva iz rodne perspektive potrebne, nalazi se $u$ različitim istraživanjima, izvještajima i preporukama. U radu se zaključuje da dalja rasprava o pravcima ove reforme treba biti urodnjena i uključivati kako institucije nadležne za pitanja rodne ravnopravnosti, tako i aktere civilnog društva i feminističke teoretičarke i aktivistkinje.

\section{O političkom predstavljanju}

Općenito se identificiraju dvije vrste argumentacija kojima se podupire teza o nužnosti ravnopravne političke participacije žena (Hughes i Paxton, 2019: 34-35). Prva vrsta je argumentacija pravde i tiče se jednostavnog demokratskog zahtjeva da žene ravnopravno s muškarcima i s obzirom na udio u ukupnom stanovništvu, učestvuju u procesima odlučivanja. Druga vrsta se tiče kvalitativnih promjena u političkom odlučivanju koje se dešavaju sa kvantitativnim povećanjem učešća žena i sabiru se velikim dijelom oko koncepta "etike brige". Međutim, dalja nijansiranja unutar ovih vrsta argumentacija, kako primjećuju Hughes i Paxton (2019: 35), zavise od toga šta podrazumijevamo pod predstavljanjem.

Naime, još 1967. godine, Hanna Fenichel Pitkin u knjizi The Concept of Representation, otvorila je širu raspravu o prirodi predstavljanja. Iako Pitkin ne izdvaja posebno probleme rodne ravnopravnosti u kontekstu političkog predstavljanja, analitičke kategorije koje je ponudila imale su važan uticaj na dalje feminističke analize. Pitkin (1972) načelno razlikuje četiri tipa predstavljanja: formalno, deskriptivno, simboličko i sustancijalno. Suština formalnog predstavljanja je prema ovoj autorici u demokratskim institucijama i procedurama kroz koje se daje ovlaštenje za zastupanje; deskripitivno predstavljanje kao korekcija formalnog predstavljanja, podrazumijeva podudarnost ili sličnost karakteristika onih koji/e predstavljaju i predstavljenih; simboličko predstavljanje odnosi se na predstavljanje ideja, stavova i uvjerenja zastupljenih 
(Pitkin, 1972). Međutim, tek u supstancijalnom predstavljanju, autorica nalazi ekvivalent za desktipivno i simboličko "zalaganje za" u području "djelovanja za” (Pitkin, 1972: 111). Rasprava koju je otvorila Pitkin, dodatno je problematizirana i obogaćena na terenu feminističkih teorijskih i empirijskih radova u kojima se razmatraju uzročno-posljedične veze između različitih vrsta predstavljanja, a posebno deskriptivnog i supstancijalnog predstavljanja. Na pitanje o odnosu između ove dvije vrste predstavljanja koja su otvorena u različitim raspravama (na pr. Tremblay, M. i Rejeal P., 2000; Čičkarić, Lj., 2014; Popov Momčinović, 2019), ne mogu se dati konačni odgovori. Štaviše, ovi, kao i neki drugi radovi, upućuju da povećanje broja žena (despkriptivno predstavljanje), ne vodi nužno i suštinskim promjenama i rodno odgovornim politikama (supstancijalno predstavljanje). ${ }^{1}$ Međutim, ovim nije dovedena $\mathrm{u}$ pitanje spomenuta argumentacija pravde, a formalno predstavljanje u demokratskim društvima ostavlja prostora i za subverzivna feministička djelovanja. Tako Manon Tremblay i Rejean Pellietier (2020), na temelju ispitivanja predstavljanja u kontekstu kanadskog parlamentarizma, zaključuju da "feministička svijest ima značajniji utjecaj od roda na mišljenja u vezi s liberalnim i rodnim pitanjima", te pretpostavljaju da se je "najbolja feministička strategija deskriptivnog i supstantivnog predstavljanja žena, promicanje žena u političkim strankama i biranje žena koje su feministkinje".

Uvijek je problematično zaključke iz ispitivanja drugih konteksta, naprosto prenositi u lokalni kontekst. U Bosni i Hercegovini nedostaju empirijska istraživanja koja se bave uzročno-posljedičnim odnosima između različitih vrsta predstavljanja. Ipak, na temelju radova koji su bili fokusirani na druge teme, te na temelju istraživanja koja se bave isključivo formalno-deskriptivnim predstavljanjem žena, moguće je izvoditi neke indirektne zaključke o suptancijalnom predstavljanju žena. Tako istraživanja u Bosni i Hercegovini pokazuju da iako su žene nedovoljno politički predstavljene, nisu apolitične. U knjizi Ženski pokret u BiH: Artikulacija jedne kontrakulture, Zlatiborka Popov Momčinović (2013) pokazuje da je u Bosni i Hercegovini od početka

\footnotetext{
${ }^{1}$ Ipak, treba uzeti u obzir da neka empirijska istraživanja potvrđuju pozitivne uticaje deskriptivnog na supstancijalno predstavljanje. Tako naprimjer, Sue Thomas (1991) pokazuje da u državama s većim postotkom žena u politici, dolazi do kvalitativnih promjenama, prije svega u sferi zakonodavnih politika. Emanuela Simona Garboni (2015) je ispitivala uticaj deskriptivnog na supstantivno predstavljanja u kontekstu nacionalnog i Evropskog parlamenta. Nalazi njenog istraživanja pokazuju pokazuju da su rumunjske žene članice Evropskog parlamenta (36\% rumunjske delegacije u analiziranom periodu), bile aktivnije u pogledu supstantivne zastupljenosti žena od svojih rumunjskih muških kolega. Suprotno tome, $u$ nacionalnom parlamentu. žene su deskriptivno nedovoljno zastupljene $(11,71 \%)$ i ni oni, ni njihove muške kolege nisu posebno aktivne/i u pogledu supstantivne zastupljenosti žena (Garboni, 2015: 85-86).
} 
'90-ih ženski pokret izuzetno značajan dio građanskog društva, da su se žene izborile za vlastiti prostor djelovanja, te da su pokretačka snaga njegovog daljeg razvoja. Istraživanja (na pr. Ždralović i Popov Momčinović, 2019) pokazuju da udruženja žena u lokalnim zajednicama često preuzima na sebe ulogu servisa za sve građanke i građane u svojoj lokalnoj zajednici, te da aktivistkinje pokazuju visok stupanj senzibiliteta za različite marginalizovane grupe i pojedinke/ce. Njihovo uključivanje u kreiranje politika i donošenje zakona predstavlja potencijal substancijalnog predstavljanja žena, ali bilo bi odveć naivno, deklarativno i populistički samo uputiti na važnost saradnje vladinog i nevladinog sektora i isključiti ih time iz procesa donošenja odluka.

Ako su, dakle, žene s entuzijazmom spremne na neformalna politička djelovanja i usmjerene na izgradnju inkluzivnijih političkih zajednica, onda ne možemo tvrditi da su apolitične, već tražiti razloge zašto nisu generalno zainteresirane za formalna politička djelovanja i osvajanja pozicija vlasti kroz političke stranke. Svakako se može pretpostaviti da stroge hijerarhijske strukture, uspostavljena muška vladavina i nemogućnost da se u tako definisanom prostoru razvijaju koncepti etike brige na kojima počivaju i ženske mirovne politike, uzrokuju velikim dijelom žensko/feminističko nepovjerenje prema pravljenu promjena "iznutra", odnosno kroz formalno političko djelovanje.

Posebno je simptomatično da se povlačenje žena iz formalne politike i intenziviranje aktivnosti žena u sferi civilnog društva, dešava paralelno sa buđenjem i jačanjem nacionalnih ideologija. Etnonacionalne matrice uslovile su i dalju političku participaciju i političko predstavljanje. U zadatim koordinatama post-socijalitičkog sistema, kroz reformu izbornog zakonodavstva mogu se tek tražiti načini ,prikladnijeg” deskriptivnog predstavljanja žena, prije svega kroz uvođenje privremenih, afirmativnih mjera. Upravo sličnost ženskih iskustava drugosti može eventualno voditi ispravljanju postojećih socioekonomskih nepravdi i rezultirati kvalitativno drugačijim politikama. Sličnost iskustava ovdje je tek uslovno pretpostavljena, a ideja o koherentnom ženskom identitetu zadržava se u ovoj raspravi u kontekstu političke reprezentacije.

Naime, u okvirima feminističkih rasprava, stav o postojanju zajedničkog interesa žena kao grupe predmet je „feminističkih sporenja” (na pr. Benhabib i dr., 2007). Ipak, sve dok možemo identificirati oblike socijalne diferencijacije između muškaraca i žena u različitim sferama, možemo identificirati i zajedničke interese, a na koncu i osnove kolektivne subjektivizacije koje su fiksirane i trajne u mjeri u kojoj su trajne i postojeće nejednakosti. Kroz debate unutar feminizama, razvija se senzibilitet za prepoznavanje različitih 
nepovoljnih položaja grupa i pojedinki/ca, ali i razara se pretpostavljeni unificirani ženski identitet. No, on je nužno i dalje pretpostavljen, jer, kako primjećuje Virginia Sapiro (1998: 167-168), ,politički sistemi vjerojatno neće predstavljati ranije nepredstavljene skupine dok te skupine ne razviju osjećaj vlastitih interesa i ne postave zahtjeve prema sistemu”, a „to zahtijeva razvoj političke svijesti i političkog aktivizma utemeljenog na toj novoj skupnoj svijesti”. Sapiro prepoznaje ulogu feminističkih pokreta u ovom podizanju svijesti, posebno na njihovim počecima.

Na ovom tragu Virginie Sapiro, ali i djelimično distancirajući se od nekih njenih zaključaka, grupni ženski identitet u daljoj raspravi u ovom radu, ne tumači se esencijalistički, niti se insistira na indikatorima snažnog osjećanja „pripadanja” grupi. Time se ne želi sporiti da za mnoga ženska/feministička udruženja i pojedinke/ce, on može biti izuzetno važan i na različite načine se artikulisati. Također, ne želi se osporiti ni važnost feminističkih poststrukturalističkih dekonstrukcija identiteta, ali im se želi suprotstaviti društvena stvarnost nejednakosti koja unatoč svim opravdanim kritikama, održava potrebu da se zadrži kolektivna subjektivizacija u feminizmima. Granice ženskih identiteta su definisane nejednakim položajima (prije svega socioekonomskim) koji su na različite načine uslovljeni rodnim stereotipima. Tako naprimjer, ekonomiju staranja (njege i brige) ,tradicionalno preovlađujuće obavljaju žene" (Đurić-Kuzmanović, 2019: 13), nivoi njihovih aspiracija, čak i u izboru zanimanje, bitno su predodređeni rodnom socijalizaciju, a napredovanje u karijeri sprječavano "staklenim stropovima". Životi žena i djevojčica, bitno su društveno definisani kroz rodne režime, a nejednake mogućnosti definišu granice kolektivnog identiteta koji nije razjedinjen samo stavovima i uvjerenjima, već i daljim ukrštanja roda s drugim osnovama diskriminacije, specifičnim ličnim iskustvima i izborima. Međutim, unatoč razjedinjenosti, upravo zajedničko iskustvo marginalizacije i isključivanja o kojem su pisale feminstkinje drugog talasa, je ono što mu omogućava da nude prepoznat sa svim svojim specifičnostima kao jedinstven kolektivni identitet.

\section{Konsocijacijski aranžmani i ignorisanje rodnih pitanja}

Nakon što su se žene izborile za puno pravo glasa, opšti trendovi su se kretali od manje od 3\% žena u parlamentima u prosjeku 1945. godine do 11,3\% mjesta 1995. godine (Hughes i Paxton, 2019: 34; IPU, 2020: 1). Upravo u posljednjih 25 godina zabilježen je značajniji napredak i porast procenta učešća žena u parlamentima širom svijeta. Odnosno, podaci generalno ukazuju 
na pozitivan trend rasta izabranih žena u nacionalnim parlamentima, koji se kretao od 11,3\% mjesta 1995. godine, do 22,1\% 2015. godine (IPU, 2020: 1). Iako se tempo napretka usporio u posljednjih pet godina, 2020. godine udio žena u nacionalnim parlamentima je blizu 25\% (IPU, 2020: 1).

Ipak, uzimajući u obzir udio ženskog stanovništva u populaciji, ovi uspjesi su ograničene naravi, te još uvijek ne možemo govoriti o rodnom paritetu u parlamentima. Uz to, za Bosnu i Hercegovinu je specifično da je bar na razini uvida u statistički pregled povijesti političke participacije žena, ovom paritetu bila bliže u socijalističkom periodu, nego danas. Odnosno, u socijalističkom periodu Bosne i Hercegovine, učešće žene je bilo procentualno na razini svjetskog prosjeka u 2020. godini, dok u vremenu buđenja etnonacionalističkih ideologija žene više nisu prisutne na političkoj sceni. Godine 1990. godine, došlo je do najvećeg pada od sticanja punog prava glasa na samo 2,92\% u Parlamentu BiH (Vidović, 1996: 6; Bakšić-Muftić i dr., 2003: 52.), a ni sa prvim poslijeratnim izborima, situacija se nije značajno promijenila.

Žene u socijalističkim državama ostvarivale su vrlo brzo nakon 1945, godine, širok spektar socijalnih i političkih prava, bez obzira na sam karakter i sadržaj ostvarenog koji se može problematizirati. S druge strane, izgradnju demokratskih društava nakon 1989. godine, pratila je repratrijarhalizacija, retradicionalizacija i reklerikarizacija društva, a ostvarena prava, uključujući i reproduktivna prava žena, prva su se našla na udaru novih demokratskih, konzervativnih politika. Kako primjećuje Žarana Papić (1997) u prikazu knjige Lydije Sklevicky Konji, žene, ratovi, iskustva bivših socijalističkih država jesu iskustva paradoksa demokratizacije budući da je riječ o tzv. „muškoj demokratiji” koja ,ženama oduzima elementarna demokratska i ljudska prava”.

U novom političkom konceptu koji se deklarativno predstavljao kao tranzicija iz autoritarnog u demokratsko, žene su pronašle mogućnost da se organiziraju u sferi civilnog društva i odgovore novim izazovima. Ipak, upravo novi koncept je privilegirajući etnonacionalne grupe i njihove interese, zatvorio prostor za druge kolektivne identitete i stvorio prepreke za uvažavanje individualnih identiteta. Ronan Kennedy, Claire Pierson i Jennifer Thomson (2016: 618) konsocijacijsku demokraciju prepoznaju kao "najutjecajniju paradigma na polju institucionalnog dizajna podjele moći i izgradnje mira nakon sukoba”. Međutim, u razvoju postkonfliktnih društveno-političkih struktura dominatna je etnonacionalna paradigma, koja "potiče zastupljenost po etničkoj ili vjerskoj liniji” i istovremeno "onemogućava učinkovito političko predstavljanje onima čiji se primarni politički identitet ne poklapa" s tim linijama (Kennedy i dr., 2016: 619). Do sličnog uklona kritike uspostavljene 
"hijerarhije" identiteta na temelju analize savremenog bosanskohercegovačkog društva, dolazi u svojim radovima i Asim Mujkić (napr., 2010: 175).

Upravo raspodjele moći na etno-nacionalnim linijama utiču na deskriptivno i supstantivno političko predstavljanje žena (Kennedy i dr., 2016: 619). U ovom radu o rodu i konsocijacijskoj podjeli moći, iznosi se još jedno važno zapažanje, a to je da, budući da je rod dio problema (sukoba), svi modeli društveno-političkog uređenja koji ga ne problematiziraju kao dio rješenja (za mir), problematični su (Kennedy i dr., 2016: 630). Međutim, s obzirom na da se u UN-ovoj agendi o ženama, miru i sigurnosti koju čini Rezolucija 1325 s devet rezolucija koje su je slijedile, prepoznaje uticaj sukoba na žene i djevojčice i problem isključivanja žena iz formalnog mirovnog procesa, - i u konsolidacijskim teorijama i u praksama postkonfliktne izgradnje društveno-političkih uređenja, ova međunarodna priznanja moraju biti uzeta u obzir kako bi se ,postigla istinski pravedna društva i održivi mir” (Kennedy i dr., 2016: 630).

Kao ilustrativan primjer način na koji su uticaji sukoba na žene i djevojčice (ne)prepoznati, a suštinski ženske (mirovne) politike ignorisane u postdaytonskog Bosni i Hercegovini, može se navesti Inicijativa za utvrđivanje Dana sjećanja na stradanje žena u ratu u Bosni i Hercegovini. Inicijativu je pokrenulo (u jesen 2014. godine) 12 ženskih organizacija koje su okupljene na projektu „Mir sa ženskim licem - Ženska inicijativa za suočavanje s prošlošću“ uz potpise oko 1200 građanki i građana. Inicijativa je dopunjena 2015. godine sa prijedlogom da za Dan sjećanja na stradanje žena u ratu BiH bude „određen neutralan datum” - 8. decembar, koji bi se obilježavao u okviru Globalne kampanje 16 dana aktivizma protiv rodno zasnovanog nasilja. U okviru Dopune ponuđeno je detaljno obrazloženje koje uključuje i detaljan istorijat ove kampanje i njen smisao, a i jasno je vidljivo nastojanje predlagačica da se uzme u obzir osjetljivost građana i građanki u oblikovanju memorijalizacije. Biranjem neutralnog datuma, predlagačice su, kako se navode u Dopuni, željele da „stradanje ljudi u ratu (žena i muškaraca)” uzdignu “iz atmosfere sveopšte politizacije" perioda od 1992-1995 te da apostrofiraju „vrednovanje ljudskih prava i života” (prema: Ždralović, 2019). Inicijativa je okupila aktivistkinje i aktiviste iz cijele $\mathrm{BiH}$, a moto njihovog okupljanja je $\mathrm{u}$ činjenici da su žene, kako se navodi u Inicijativi, isključene iz procesa memorijalizacije te da se ,ukupna, a ni pojedinačna stradanja žena ni na koji način ne obilježavaju" (prema: Ždralović, 2019). Iako do institucionalizacije Dana sjećanja nije došlo, aktivistkinje i aktivisti ga i dalje neformalno obilježavaju. 
Ženski mirovni aktivizmi koriste sferu civilnog društva za djelovanje u javnom prostoru, ali njihovi glasovi su ignorisani u „formalnoj” politici.

Još se u Konvenciji o eliminaciji svih oblika diskriminacije žena (CEDAW) koja je usvojena na Generalnoj skupštini UN-a 18. decembra 1979. godine, od država potpisnica zahtijeva da poduzmu ,sve moguće mjere da eliminišu diskriminaciju nad ženama u političkom i javnom životu zemlje" te da, između ostalog, osiguraju ženama, u jednakoj mjeri kao i muškarcima, pravo da učestvuju „u formulisanju vladine politike i implementacije i da imaju javni ured i vrše sve javne funkcije na svim nivoima vlade”, kao i „u nevladinim organizacijama i udruženjima koja su uključena u javni i politički život zemlje”, (član 7) te da poduzmu ,sve moguće mjere da osiguraju da žene, jednako kao muškarci, bez diskriminacije, imaju mogućnost da predstavljaju Vlade na međunarodnom nivou i da učestvuju u radu međunarodnih organizacija" (član 8). Ova Konvencija, kao i drugi standardi usvojeni u UN-ovoj Dekadi žena, nije stavila direktan fokus na pitanje roda, sigurnosti i mira, ali je opštim smjernicama ostavila prostora za šira tumačenja koji (uglavnom) nije iskorišten. Tek u Pekinškoj deklaraciji i Platformi za akciju koja je usvojena u septembru 1995. godine, izričito se ukazuje na značaj uključivanja žena u formalne procese odlučivanja o pitanjima vezanim za mir i sigurnost. U decembru iste godine potpisan je Dejtonski mirovni sporazum - ,prvi veliki mirovni sporazum koji je bio potpisan nakon konferencije u Pekingu” (Kvinna till Kvinna, 2000: 9). U osnovi, ovaj mirovni pregovor bio je „dijalog muškaraca, često s čisto militarističkim prizvukom” (Kvinna till Kvinna, 2000: 20). Time su žene isključene iz ugovora o političkoj zajednici i supstancijalno ostaju isključene iz daljih procesa odlučivanja, a njihove inicijative koje dolaze iz sfere građanskog društva, ignorišu se.

U oktobru 2000. godine usvojena je spomenuta Rezolucija 1325 o ženama, miru i sigurnosti. Bosna i Hercegovina je prva u regiji jugoistočne Evrope izradila Akcioni plan za implementaciju UNSCR 1325 u Bosni i Hercegovini (AP UNSCR $1325 \mathrm{u} \mathrm{BiH}$ ). ${ }^{2}$ Akcioni planovi Bosne i Hercegovine su prepoznati kao primjeri dobre prakse (Myrttinen i dr., 2020; ARSBiH, 2019: 6). Nije sporno da je značaj Rezolucije 1325 prepoznat od strane nadležnih institucija (a prije svega Agencije za ravnopravnost spolova Bosne i Hercegovine - ARS BiH), feminističkih udruženja i aktivistkinja, te da su uloženi napori na njenu provedbu. Najvidljiviji rezultati su postignuti na povećanju učešća žena u vojsci, policiji i mirovnim misijama (ARSBiH, 2017), ali mišljenja

${ }^{2}$ Prvi Akcioni plan u Bosni i Hercegovini je proveden u periodu 2010. -2013., drugi u periodu 2014. 2017., dok se treći plan za 2018. -2022. trenutno provodi. 
feministkinja su podijeljena po pitanju interpretacije ovih napredaka. Tako naprimjer, Lepa Mlađenović i Biljana Branković (2013: 3) predstavljaju istoriju međunarodnog mirovnog pokreta koji je doveo do Rezolucije 1325, ali već na početku studije napominju da se "krajnji tekst Rezolucije razlikuje od idejnog, dok je njegova implementacija još dalja od vizija kreatorki”. Posebno razočarenje se izražava zbog toga što je suprotno "feminističkim težnjama” primjena Rezolucije 1325 “svedena (samo) na povećanje broja žena u vojsci i policiji ili na povećanje broja žena u drugim (muškim) centrima moć" (Mlađenović i Branković, 2013: 18). Ovakvim zapažanjima treba dodati i sve feminističke polemike koje se razvijaju generalno oko interpretacije Rezolucije 1325 i njene dalje primjene u različitim kontekstima (Subotić i Zajović, pr., 2012; Ždralović i dr., 2020).

Dok su u sektoru odbrane i sigurnosti postignuti vidljivi napreci o čijem karakteru bi se dalo raspravljati, ,u pogledu ostvarivanja građanskih i političkih prava žena u $\mathrm{BiH}$ i dalje je prisutna kontinuirana nejednakost, podzastupljenost žena i kršenje odredbi ZoRS [Zakona o ravnopravnosti spolova]u BiH]" (ARSBiH, 2019: 9). Ako se pogleda statistika u Bosni i Hercegovini u posljednjih 25 godina - dakle period nakon Pekinške deklaracije i Daytonskog mirovnog sporazuma - može se zaključiti da unatoč prihvaćenim standardima, ciljevi ravnopravnog učešća žena i muškaraca u procesima odlučivanja, nisu ostvareni. Neke pozitivne tendencije u pogledu deskriptivnog predstavljanja, mogu se identifikovati. ${ }^{3}$ Dok je period od 1992. do 1997. godine period vidljivog odsustva žena na mjestima odlučivanja, 1998. godine došlo je do rasta broja izabranih žena: u Predstavničkom domu Parlamenta $\mathrm{BiH}$ žene dobile 26\%, u Predstavničkom domu FBiH 15\%, u Narodnoj skupštini RS 22,8\%, a na kantonalnim nivoima 18,46\% mjesta (Bakšić-Muftić i dr., 2003: 52). Model zatvorenih listi sa ženskim kvotama ${ }^{4}$, prema mišljenju mnogih

\footnotetext{
${ }^{3}$ Prilikom identifikacije opštih pozitivnih tendencija u daljoj raspravi, u obzir treba uzeti i odsustvo žena iz Predsjedništva BiH, izrazito nedovoljno prisustvo u izvršnoj vlasti i izrazito visok postotak žena u pravosudnim institucijama BiH. U Izvještaju Agencije za ravnopravnost spolova iz novembra 2019. godine kao značajan problem u oblasti učešća žena u političkom i javnom životu, prepoznaje se parcijalna primjena ženske kvote propisane ZoRS-om BiH, "koja se i dalje ne primjenjuje dosljedno prilikom imenovanja u izvršnu vlast, odbore javnih preduzeća itd."

${ }^{4}$ Zakonodavac koristi termin "manje zastupljeni spol", ali su teorijski prihvatljivi i pojmovi "ženske kvote" i "rodne kvote". U ovom radu se preferira upotreba termina “ženske kvote", jer ona za razliku od neutralnog termina (a prebacivanje na neutralan teren je svojstveno patrijarhalnim strategijama) jasno ukazuje da su žene te koje su izostavljene iz raspodjele (političke) moći. Upotreba termin "rodne kvote" zavisi od toga kako razumijemo rod. Upotreba ovog termina kao socijalnog konstrukta koji objašnjava specifične i patrijarhalno definisane pozicije i uloge žena, bila bi opravdana. Međutim, može se stvoriti pogrešan dojam da će sa ovakvim pojmovima biti riješeni i problemi intersekcionalnost i individualnih izražavanja rodnih identiteta u kontekstu političkog predstavljanja.
} 
autora/ica (na pr. Miftari, 2015: 18; Aganović i dr., 2015: 14), odrazio se pozitivno na političku participaciju žena 1998. godine.

Godine 2000. dolazi do promjene izbornih pravila, a proporcionalni izborni model otvorenih listi uz zadržavanje kvota, doveo je značajnog pada učešća žena u politici u odnosu na 1998. godinu. U Parlamentarnoj skupštini BiH izabrano je 4,76\% žena, u Predstavničkom domu Parlamenta FBiH 17,4\%, a u Narodnoj skupštini RS 14,86\% (Miftari, 2015: 18). U proteklih 20 godina, generalno se bilježi stagnacija broja izabranih zastupnica sa neznatnim oscilacijama. Ukupan broj izabranih kandidatkinja u Bosni i Hercegovini 2002. godine iznosio je 20,15\%, a 2006-17,21\% (CIK, 2015). Ukupan broj žena izabranih na izborima 2010. godine bio je 17,37\%, dok je ukupan broj izabranih žena u zakonodavna tijela na izborima 2014. godine iznosio 18.9\% (CIK, 2015). Relativno značajnija oscilacija bilježi se 2018. godine, kada je ukupan postotak izabranih kandidatkinja iznosio 27,41\% (CIK, 2019).

U periodu od 2003. do 2013. godine, u različitim istraživanjima, izvještajima, ali i vladinim i nevladinim inicijativama koje se odnose na političko učešće žena, kao centralni problem se prepoznaje neusklađenost Izbornog zakona BiH sa Zakonom o ravnopravnosti spolova BiH. Naime, Zakon o ravnopravnosti spolova $\mathrm{BiH}$ koji je usvojen 2003. godine, propisuje obavezan minimalnu udio „manje zastupljenog spola” od 40\%, u tijelima zakonodavne, izvršne i sudske vlasti. S druge strane, Izbornim zakonom BiH bilo je predviđeno da svaka lista mora imati najmanje trećinu mjesta rezervisanu za osobe "manje zastupljenog spola", a da među prvih 10 kandidata/kandidatkinja moraju biti najmanje tri kandidata/kandidatkinje „manje zastupljenog spola”. Razmatrajući različita moguća rješenja, ustanovljeno je da bi se tek zatvaranjem kandidatskih lista osiguralo najmanje 40\% stvarnog učešća žena. ${ }^{5}$ Međutim, u izmjenama Izbornog zakona Bosne i Hercegovine 2013. godine, ignorisane su ove preporuke, te je u tzv. ženskoj kvoti obavezan procenat manje zastupljenog spola povećan sa $30 \%$ na $40 \%$ na otvorenim listama. Povećanje kvote protumačeno je kao usklađivanje Izbornog zakona BiH sa

\footnotetext{
${ }^{5}$ Već je Venecijanska komisija u svom mišljenju o izmjenama i dopunama Izbornog zakona BiH konstatovala da će postizanje cilja povećanja broj izabranih žena bit otežano „u postojećem sistemu glasanja po otvorenim listama, koji omogućava glasačima da zanemare raspored kandidata na listama" (ARSBiH, 2011: 72). Radna grupa za izmjene i dopune Izbornog zakona Bosne i Hercegovine, koju je formirala Komisija za ostvarivanje ravnopravnosti spolova Predstavničkog doma Parlamentarne skupštine BiH, ustanovila je da bi se ,zatvaranjem kandidatskih lista osiguralo najmanje $40 \%$ učešće žena u parlamentima, čime bi se osigurala kritična masa zastupljenosti žena u parlamentima, te ispoštovali međunarodni standardi u toj oblasti”. I u Zaključnim zapažanjima CEDAW Komiteta na posljednji, šesti periodični izvještaj $\mathrm{BiH}$, izražava se zabrinutost zbog "uvođenja sistema otvorene liste izmjenama i dopunama Izbornog zakona Bosne i Hercegovine 2013. godine koji je nepovoljan za kandidatkinje" (2019: 8).
} 
Zakonom o ravnopravnosti spolova $\mathrm{BiH}$, mada se kvote u prvom odnose na zastupljenost na kandidatskim listama, a u drugom na stvarnu zastupljenost žena u tijelima na svim nivoima vlasti do kojih zakonske reforme izbornog zakonodavstva na kraju nisu dovele.

Stoga je potrebno opet otvoriti rasprave o mogućim pozitivnim učincima zatvaranja izbornih lista na formalno-deskriptivno predstavljanje žena. Pri tome sve kritike kvota i zatvorenih listi moraju uzeti u obzir činjenicu da su etno-nacionalne ideologije dovele do repatrijarhalizacije i retradicionalizacije društva, te da su etno-nacionalni kolektiviteti u političkom sistemu već privilegovani kroz osigurana mjesta odlučivanja i veto po osnovu vitalnog interesa kojim raspolažu konstitutivni narodi. Stoga kritike feminističkih prijedloga moraju ili ponuditi pravce temeljite i urodnjene preobrazbe sistema ili još jednom preispitati osnovanost svojih prijedloga u okolnostima postojećeg sistema. Feminističke teoretičarke i aktivistice, kao naprimjer Jelena Višnjić (2016: 167), svjesne su da su ženske kvote ,afirmativna i privremena stimulativna mjera, ali nedovoljna da bi žene ostvarile punu ravnopravnost u okviru svojih stranaka i/ili političkog sistema". Međutim, one su u okolnostima postkonfliktne izgradnje društva nužne radi ravnopravnog formalno-deskriptivnog sudjelovanja žena u raspodjeli moći. Međutim, kako se primjećuje u Platformi za akciju Pekinške deklaracije, uz adekvatno predstavljanje na svim nivoima odlučivanja, žene moraju biti i „osnažene politički i ekonomski” (stav 134). Može se zaključiti da sve privremene mjere koje se poduzimaju radi veće političke participacije žena, trebaju biti praćene složenim radom na promicanju rodne ravnopravnosti u svim drugim sferama.

U dalje rasprave o reformama izbornog zakonodavstva u Bosni i Hercegovini koje su potrebne iz rodne perspektive ${ }^{6}$, svakako je nužno uključivati institucije nadležne za pitanja rodne ravnopravnosti, feministička udruženja i feminističke teoretičarke i aktivistkinje. Upravo u sferi civilnog društva, pokrenute su značajne inicijative koje u daljim dijalozima ne mogu biti ignorisane. Jedna od takvih inicijativa koja je 2013. godine je inicijativa Građanke za ustavne promjene (koja okuplja organizacije civilnog društva i aktivistkinje) u okviru koje je napravljena i Platforma ženskih prioriteta za ustavne promjene. U ovom dokumentu kao prioritetne oblasti se navode: 1)

\footnotetext{
${ }^{6} \mathrm{Na}$ ovu potrebu ukazano je i u Zaključnim zapažanjima CEDAW Komiteta na posljednji, šesti periodični izvještaj Bosne i Hercegovine. Odbor preporučuje da se razmotri zamjena "sistema otvorene liste sistemom 'zatvarača' za imenovanje kandidata oba spola na izbornim listama političkih stranaka, osiguravanjem da se prvi od svakog para naknadnih rang-lista na izbornim listama dodijeli ženi kandidatkinji i da se uvedu rezervirana mjesta za žene u parlamentima svih entiteta" (CEDAW Komitet, 2019: 8-9).
} 
upotreba rodno-odgovornog jezika u Ustavu Bosne i Hercegovine; 2) uvođenje afirmativnih mjera u Ustav Bosne i Hercegovine radi postizanja pune rodne i spolne ravnopravnosti; 3) proširenje postojećeg Kataloga prava odredbama u vezi sa jedinstvenom zdravstvenom, socijalnom i porodičnom zaštitom; 4) veća sudska i pravna zaštita ljudskih prava i sloboda; 5) princip direktne demokratije primijenjen na proces ustavne reforme (Inicijativa građanske za ustavne promjene, 2013). Realizacija ovakvih sveobuhvatnijih prijedloga, vodi ka stvaranju pretpostavki za supstancijalo predstavljanje žena, što bi dalje značilo i odgovornije i osjetljivije politike za različite marginalizirane grupe i pojedinke/ce.

\section{Zaključak}

Formalno (političko) predstavljanje u postdaytonskoj Bosni i Hercegovini definisano je etno-nacionalnim ideologijama. Ono uistinu omogućava deskriptivno predstavljanje i ženama koje pripadaju „konstitutivnim” kolektivitetima, ali učešće koje je usmjereno djelovanjem patrijarhalnih rodnih režima i u minimalnom nužnom postotku. Simboličko predstavljanje ženskih/feminističkih ideja, stavova i uvjerenja dešava se slučajno i sporadično, a supstancijalno "djelovanje za" uglavnom izostaje. Iako načelno statistički podaci o političkom učestvovanju žena u Bosni i Hercegovini u posljednjih 20 godina ne odstupaju bitno od svjetskih prosjeka, sami načini političkog predstavljanja uokvireni u patrijarhalno prihvatljivo.

Reforme izbornog zakonodavstva iz rodne perspektive, nužne su. Međutim, one moraju kroz dijalog biti dobro osmišljene, jer dosadašnja iskustva (naprimjer, načina usklađivanja Izbornog zakona Bosne i Hercegovine sa Zakonom o ravnopravnosti spolova) pokazuje da se reforme provode formalno, a prijedlozi koji dolaze iz feminističkih krugova, ignorišu se. Otvaranje prostora za političko predstavljanje žena, omogućilo bi dalje kreiranje rodno osjetljivih politika, a u konačnici beneficije bi imalo cjelokupno društvu. Međutim, prethodno već u svaku raspravu o reformama izbornog zakonodavstva tu Bosni i Hercegovini, treba uključiti i rodnu perspektivu.

Pri tome treba imati na um da osmišljavanje posebnih mjera za političko (prije svega formalno-deskriptivno) predstavljanje žena, uobičajeno računa s kolektivnim identitetom, koji je u ovom slučaju nehomogen. Ali upravo ta unutrašnja razjedinjenost i feminističke nesuglasice oko sadržaja kategorije u čije ime treba da se zagovara i djeluje, čine ga osjetljivim na sve najraznovrsnije razlike i daju mu kreativni potencijal u daljem osmišljavanju politika. 
Prepoznavanje i priznavanje takvog kolektiviteta u kontekstu bosanskohercegovačkog društveno-političkog sistema, u osnovi je priznavanje narušenosti komutativnog principa pravde i pokušaj korekcije raspodjele moći kako bi se osigurale jednake mogućnosti za pojedinke/ce.

\section{Literatura}

Aganović, A., Miftari, E., Veličković, M. (2015). 1995-2015: Žene i politički život u postdejtonskoj Bosni i Hercegovini. Sarajevo: Sarajevski otvoreni centar i Agencija za ravnopravnost spolova $\mathrm{BiH}$.

Agencija za ravnopravnost spolova Bosne i Hercegovine - ARS BiH. (april, 2019). Izvještaj o napretku u primjeni Pekinške deklaracije i Platforme za djelovanje u $\mathrm{BiH}$ u okviru procesa Peking +25. Preuzeto 21. 9. 2020. https://arsbih.gov.ba/wp-content/uploads/2019/05/ Izvjestaj-o-napretku-Peking25 Bosna-i-Hercegovina.pdf.

Agencija za ravnopravnost spolova Bosne i Hercegovine - ARS BiH. (novembar, 2019). Izvještaj o implementaciji Gender akcionog plana Bosne i Hercegovine 2018-2022. godina (izvještajni period: novembar 2018 - septembar 2019). Preuzeto 25. 9. 2020. https:// arsbih.gov.ba/wp-content/uploads/2020/07/Izvjestaj-GAP-2018-19.pdf.

Agencija za ravnopravnost spolova Bosne i Hercegovine - ARS BiH. (oktobar, 2017). Završni izvještaj o provedbi Akcionog plana za implementaciju UN Rezolucije 1325 ,Žene, mir i sigurnost“" u BiH 2014-2017. godina. Preuzeto 15. 2. 2020. https://arsbih.gov.ba/wpcontent/uploads/2018/01/Zavrsni-izvjestaj_AP-UNSCR_2014-2017.pdf

Agencija za ravnopravnost spolova Bosne i Hercegovine - ARS BiH. (2011). Priručnik za usklađivanje zakona sa Zakonom o ravnopravnosti spolova i sa međunarodnim standardima u oblasti ravnopravnosti spolova. Sarajevo: Agencija za ravnopravnost spolova Bosne i Hercegovine, Ministarstva za ljudska prava i izbjeglice Bosne I Hercegovine; Razvojni program Ujedinjenih Nacija, uz podršku Fonda za razvoj Japanske Vlade. Preuzeto 15. 9. 2020. https://www.gcfbih.gov.ba/wp-content/uploads/2014/01/prirucnik_uskladjivanje.pdf.

Bakšić-Muftić, J., Ler-Sofronić, N., Gradaščević-Sijerčić, J., Fetahagić, M. (2003). Socio - Economic Status of Women in Bosnia and Herzegovina: Analysis of the results of star pilot research done in 2002. Sarajevo: Jež

Benhabib, S., Batler, Dž., Kornel, D. i Frejzer N. (2007). Feministička sporenja: filozofska razmena. (J. Blagojević, prev.). Beograd: Beogradski krug.

CEDAW Komitet. (2019). Zaključne napomene o šestom periodičnom izvještaju Bosne $i$ Hercegovine, CEDAW/C/BIH/CO/6 (preliminarna neredigirana verzija). Preuzeto 21.10.2019. https://arsbih.gov.ba/zakljucna-zapazanja-na-sesti-periodicni-cedaw/.

Centralna izborna komisija-CIK. (2015). Izborni pokazatelji 2002-2014. Preuzeto 27. 2. 2020. https:/www.izbori.ba/Documents/2015/25052015/Izborni_Pokazatelji_2002-2014.pdf

Centralna izborna komisija - CIK.. (2019). Izborni pokazatelji 2018. Preuzeto 27. 2. 2020. https://www.izbori.ba/Documents/2019/11/Izborni_pokazatelji_2018.pdf.

Garboni, E.S. (2015). The impact of descriptive representation on substantive representation of women at European and national parliamentary levels. Case Study: Romania. Procedia - Social and Behavioral Sciences, 183. (str. 85-92).

Čičkarić, Lj. (2014). Da li žene predstavljaju žene u parlamentu?. U: Genero, br. 8. (str. 135-153).

Đurić-Kuzmanović, T. (2019). Feministička ekonomija kao škola mišljenja. U: A. Ždralović, pr. Rod i ekonomija. Sarajevo: Sarajevski otvoreni centar. (str. 9-17). 
Hughes, M.M i Paxton, P. (2019). The Political Representation of Women over Time. U: S. Franceschet, M. Lena Krook i N. Tan The Palgrave Handbook of Women's Political Rights (str. 33-51). Palgrave Macmillan.

Inicijativa građanke za ustavne promjene. (2013). Platforma ženskih prioriteta za ustavne promjene sa amandmanima na Ustav Bosne i Hercegovine iz rodne perspektive. Preuzeto 1. 7. 2018. https://gradjankezaustavnepromjene.wordpress.com/platformu-zenskih-prioriteta

Inter-Parliamentary Union. (2020). Women in parliament: 1995-2020. Preuzeto 26. 9. 2020. https://www.ipu.org/resources/publications/reports/2020-03/women-in-parliament1995-2020-25-years-in-review.

Izborni zakon BiH. Službeni glasnik BiH, br. 23/01, 7/02, 9/02, 20/02 , 25/02, 4/04, 20/04, 25/05, 52/05, 65/05, 77/05, 11/06, 24/06, 32/07, 33/08, 37/08, 32/10, 18/13, 7/14 i 31/16.

Kennedy, R., Pierson, C. i Thomson, J. (2016). Challenging identity hiearchies: Gender and consociational power-sharing. The British Journal of Politics and International Relations, Vol. 18 (3). (str, 618-633).

Konvencija o ukidanju svih oblika diskriminacije žena, preuzeto 10. 3. 2013. http://www. arsbih.gov.ba/images/documents/Idoc/cedaw.pdf.

Kvinna till Kvinna. (2000). Engendering the Peace Process: A Gender Approach to Dayton and Beyond. Stockholm: The Kvinna till Kvinna Foundation.

Miftari, E. (2015). Politička participacija žena u Bosni i Hercegovini: Analiza učešća žena na stranačkim listama i konačnih rezultata općih izbora 2014. Sarajevo: Fondacija Cure i SOC. Preuzeto 3.2.2020- http://zenskamreza.ba/site/wp-content/uploads/2015/02/Mapa Politicka-participacija_Edita_Knjizni-blok_Za-stampu.pdf

Mlađenović, L. i Branković, B. (2013). Međunarodni feministički mirovni pokret koji je doveo do Rezolucije 1325. Beograd : Beogradski centar za bezbednosnu politiku.

Mujkić, A. (2010). Pravda i etnonacionalizam. Sarajevo: Centar za ljudska prava Univerziteta u Sarajevu i Fondacija Heinrich Böll - Ured u Sarajevu.

Myrttinen, H., Shepherd, L.J. i Wright, H. (2020). Implementing the Women, Peace and Security Agenda in the OSCE Region. Beč: OSCE. Preuzeto 7. 4. 2020. https://www.osce. org/secretariat $/ 444577$ ?download=true.

Papić, Ž. (1997). Lydia Sklevicky ili mape alternativnih strategija: Spisateljica i njena sjena. Ženske studije, 8-7. Preuzeto 5. 12. 2019. http://www.womenngo.org.rs/sajt/sajt/izdanja/ zenske_studije/zs_s8/lidija.html

Pekinška deklaracija i Platforma za akciju. Preuzeto 10. 3. 2014. https://arsbih.gov.ba/wpcontent/uploads/2014/01/04-PEKINSKA-DEKLARACIJA-kb.pdf

Pitkin, H. F. (1972). The Concept of Representation. Berkley/Los Angeles/London: University of California Press.

Popov-Momčinović, Z. (2013). Ženski pokret u BiH: Artikulacija jedne kontrakulture. Sarajevo: Sarajevski otvoreni centar, Centar za empirijska istraživanja religije u $\mathrm{BiH}$ i Fondacija CURE.

Popov-Momčinović, Z. (2019). Rodna ravnopravnost i politički i javni život. U: A. Ždralović i S. Gavrić Uvod u rodne studije. Teorija, pravo, politika - za studentice i studente društvenih nauka Sarajevo: Sarajevski otvoreni centar i Pravni fakultet. (str. 155-170).

Rezolucija 1325 (2000). Preuzeto 8. 3. 2013. http://www.1325.arsbih.gov.ba/?page_id=265

Sapiro, V. (1998). When are Interests Interesting? The Problem of Political Representation of Women. U: A. Phillips Feminism and Politics. Oxford/New York: Oxford University Press. (str. 161-191). 
Subotić, G. i Zajović, S., pr. (2012). Feminističkoantimilitaristički pristup konceptu, tumačenju i praksi Rezolucije 1325. Beograd: Žene u crnom.

Thomas, S. (1991). The Impact of Women on State Legislative Policies. The Journal of Politics. Vol. 53, No. 4. (str. 958-976).

Tremblay, M. i Pellietier, R (2000). More Feminists or More Women?: Descriptive and Substantive Representations of Women in the 1997 Canadian Federal Elections. U: International Political Science Review, Vol.21, No. 4. (str. 381-405). Preuzeto 15.9.2020. https:// journals.sagepub.com/doi/10.1177/0192512100214004

Višnjić, J. (2016). Rodna analiza teksta u 'online' štampanim medijima u Srbiji. (doktorska disertacija), Univerzitet u Novom Sadu, Asocijacija centara za interdisciplinarne i multidisciplinarne studije i istraživanja, Centar za rodne studije. Preuzeto 10. 9. 2020. http:// www.zenskestudije.org.rs/pdf/doktorske/Jelena\%20Visnjic_doktorska\%20disertacija.pdf.

Zakon o ravnopravnosti spolova $\mathrm{BiH}$. Službeni glasnik BiH, 16/03 i 102/09. Preuzeto 15. 1. 2020. https://arsbih.gov.ba/wp-content/uploads/2014/01/ZoRS 32_10_B.pdf.

Ždralović, A. i Popov-Momčinović, Z. (2019). Aktivizmi s marginä: procjena kapaciteta deset odabranih ženskih organizacija. Sarajevo: Sarajevo: Fondacija CURE.

Ždralović, A. (2109). Istorijat (pokušaja) institucionalizacije jednog sjećanja. Balkan perpectives, 11/06. (str. 26-27).

Ždralović, A., Gavrić, S. i Rožajac-Zulčić, M., pr. (2020). Kojeg je roda sigurnost? 20 godina Rezolucije Vijeća sigurnosti 1325 "Žene, mir i sigurnost" i njezina provedba u Bosni $i$ Hercegovini. Sarajevo: Sarajevski otvoreni centar.

\section{Electoral Legislation in Bosnia and Herzegovina - Gender Analysis}

\section{Summary}

Abstract: The paper presents a gender needs analysis and possible directions of electoral legislation reforms in Bosnia and Herzegovina. The paper focuses on three core research questions. The first examines to what extent and how do consociational political systems (dis)enable the representation of women in politics. It also looks at the different dimensions of that representation (formal, descriptive, substantial and symbolic). The second examines whether the Election Law of Bosnia and Herzegovina is harmonised with the Gender Equality Law of Bosnia and Herzegovina. And the third examines the direction in which electoral legislation reforms in $\mathrm{BiH}$ should and could take place. In that context, the paper also presents recommendations from CEDAW and various other gender mainstreaming initiatives focused on electoral legislation reforms, coming both from the institutions in charge of gender equality and from the civil society.

Key words: political participation of women, women's quota / gender quota, affirmative measures, Election Law of $\mathrm{BiH}$. 